\title{
Specific CD8 T Cells in IgE-mediated Allergy Correlate with Allergen Dose and Allergic Phenotype
}

\author{
Juan A. Aguilar-Pimentel ${ }^{1}$, Francesca Alessandrini ${ }^{2,3}$, Katharina M. Huster ${ }^{4,5}$, Thilo Jakob6, Holger Schulz ${ }^{7}$, \\ Heidrun Behrendt ${ }^{2,3}$, Johannes Ring1,2, Martin Hrabé de Angelis ${ }^{8}$, Dirk H. Busch ${ }^{4,5}$, Martin Mempel ${ }^{1,2 *}$, \\ and Markus Ollert ${ }^{1 *}$
}

\begin{abstract}
${ }^{1}$ Department of Dermatology and Allergy, Biederstein, Technische Universität München, and Clinical Research Division of Molecular and Clinical Allergotoxicology, Technische Universität München, Munich; ${ }^{2}$ Division of Environmental Dermatology and Allergy TUM/ Helmholtz Zentrum München, German Research Center for Environmental Health, Neuherberg; ${ }^{3}$ Focus Network Nanoparticles and Health (NanoHealth), Helmholtz Zentrum München, German Research Center for Environmental Health (GmbH), Neuherberg; ${ }^{4}$ Institute of Microbiology, Immunology, and Hygiene, Technische Universität München, Munich; ${ }^{5}$ Clinical Cooperation Groups 'Antigen-Specific Immunotherapy' and 'Immune-Monitoring', Helmholtz Zentrum München, German Research Center for Environmental Health, Neuherberg and Technische Universität München, Munich; ${ }^{6}$ Allergy Research Group, University Medical Center Freiburg, Freiburg; ${ }^{7}$ Institute for Inhalation Biology, Helmholtz Zentrum München, German Research Center for Environmental Health, Neuherberg; and ${ }^{8}$ Institute of Experimental Genetics, Helmholtz Zentrum München, German Research Center for Environmental Health, Neuherberg, Germany
\end{abstract}

Rationale: Studies in humans and rodents have indicated a causative role for $\mathrm{CD8}^{+} \mathrm{T}$ cells in IgE-mediated allergic inflammation, but their function is still controversial.

Objectives: To analyze the role of allergen-specific $\mathrm{CDB}^{+} \mathrm{T}$ cells during the development of allergic airway inflammation in two parallel but diverging outcome models.

Methods: We used H2-Kb SIINFEKL (OVA $257-264)$ multimers to analyze induction, natural distribution, and phenotype of allergen-specific $\mathrm{CD8}^{+}$ T cells in a murine C57BL/6 model of ovalbumin (OVA)-induced allergic airway inflammation using low-dose or high-dose OVA sensitization. Measurements and Main Results: The low-dose protocol was characterized by a significant induction of total and OVA-specific $\lg \mathrm{E}$, eosinophilic airway inflammation, IL-4 levels in bronchoalveolar lavage fluid. And significant alterations in lung function. The high dose protocol was characterized by a significant reduction of the allergic phenotype. Using OVA $257-264 \mathrm{H} 2-\mathrm{Kb}$ multimers, we observed lung and airway infiltrating OVA-specific CD8 ${ }^{+} \mathrm{T}$ cells showing an effector/effectormemory phenotype. The high-dose protocol caused significantly higher infiltration of allergen-specific $\mathrm{CDB}^{+}$cells to the airways and enhanced their cytotoxicity. Adoptive transfer with $\mathrm{CDB}^{+} \mathrm{T}$ cells from transgenic OT-I mice to TAP1 ${ }^{-1-}$ or wild-type mice showed their migration to the lungs and TAP1-dependent proliferation after OVAaerosol exposure. TAP1 ${ }^{-/-}$mice defective in $\mathrm{CDB}^{+} \mathrm{T}$ cells showed exacerbated symptoms in the low-dose sensitization model. Conclusions: Allergen-specific $\mathrm{CD8}^{+} \mathrm{T}$ cells seem to protect from allergic inflammation in the lungs. Their number, which is dependent on the sensitization dose, appears to be a critical predictor for the severity of the allergic phenotype.

Keywords: cytotoxicity; tolerance; airway inflammation; asthma; immunotherapy

(Received in original form February 6, 2009; accepted in final form October 7, 2009) Supported by grant $01 \mathrm{CC} 0104$ (Klinische Forschergruppe) from the German Federal Ministry of Education and Science (BMBF) (M.O.), by BMBF subproject grant 01GC0104-TP4 (M.M. and M.O.), grants from the German National Genome Research Networks NGFN-1 (Allergy screen) (H.B. and M.O.) and NGFN-2 (German Mouse Clinic/GMC [M.H.A.] and GMC Immunology screen [D.H.B.]; GMC Allergy screen 01GR0458, to M.O.) and institutional KKF grants from the University Hospital "Klinikum rechts der Isar," Technische Universität München (TUM) to M.M. and M.O. M. Mempel was supported by a Heisenberg career development grant from the Deutsche Forschungsgemeinschaft (DFG) (Me 1708/2-1).

* These authors contributed equally to this work.

Correspondence and requests for reprints should be addressed to Prof. Markus Ollert, M.D., Department of Dermatology and Allergy, Biederstein Technische Universität München Biedersteiner Str. 29 D-80802 München, Germany. E-mail: ollert@Irz.tum.de This manuscript has an online supplement, which is accessible from this issue's table of contents at www.atsjournals.org

Am J Respir Crit Care Med Vol 181. pp 7-16, 2010

Originally Published in Press as DOI: 10.1164/rccm.200902-01900C on October 8, 2009 Internet address: www.atsjournals.org

\section{AT A GLANCE COMMENTARY}

Scientific Knowledge on the Subject

Previous studies have indicated a divergent role for specific $\mathrm{CD} 8^{+} \mathrm{T}$ cells in allergic airway disease. To address this controversy, opposing priming conditions for $\mathrm{CD} 8^{+} \mathrm{T}$ cells using high- or low-dose allergen concentrations were applied.

What This Study Adds to the Field

The recruitment of functionally active allergen-specific $\mathrm{CD} 8^{+} \mathrm{T}$ cells to the airways, which is dependent on the allergen sensitization dose, appears to be a critical predictor for the severity of the allergic phenotype in mice.

Atopic allergic conditions such as asthma, allergic rhinoconjunctivitis, or atopic dermatitis are characterized by an increase in allergen-specific IgE and CD4 ${ }^{+} \mathrm{T}$ cell responses (1). $\mathrm{CD} 8^{+} \mathrm{T}$ cells, which provide protective immunity against viral and bacterial pathogens, are considered to be less important $(2,3)$. However, several reports using gene knock-out strategies or adoptive cell transfer in murine models have pointed out a crucial role of $\mathrm{CD} 8^{+} \mathrm{T}$ cells in allergic airway inflammation and in $\mathrm{IgE}$ regulation (4-7). Moreover, house dust mite allergen (Der $\mathrm{p} 1$ )-specific $\mathrm{CD} 8^{+} \mathrm{T}$ cells have been identified in patients with atopic dermatitis, and their presence was correlated to a favorable clinical course (8). For the development of allergenspecific $\mathrm{CD}^{+} \mathrm{T}$ cells, soluble allergens are captured by local antigen-presenting cells and presented by MHC class I molecules (cross-presentation) (9-11). Major obstacles in fully understanding the functional role of allergen-specific $\mathrm{CD}^{+} \mathrm{T}$ cells in allergic inflammation are the diverging results obtained in previous studies showing a protective $(7,12-15)$ or an aggravating role $(4,16-18)$ or both $(5)$, depending on the experimental conditions. From a therapeutic point of view, evidence has been provided that IgE-mediated, Th2 cytokine-dominated allergic diseases can be modulated toward a state of allergen tolerance through allergen-specific immunotherapy (SIT) (19, $20)$ or by natural course $(21,22)$. During SIT, immune modulation toward an IgG4- and IL-10-dominated response is accomplished by repetitive application of excessive amounts of allergenic antigen over several years $(23,24)$. In various studies, a positive correlation has been demonstrated between the antigen/allergen dose and the clinical success of SIT (25-27). 
Thus, both the dose-response relationship and the incremental application of abundant antigen concentrations during SIT constitute interesting immunological models to analyze the cross-presentation of external peptides together with the induction of allergen-specific CD8 ${ }^{+} \mathrm{T}$ cells.

To analyze the natural induction and organ distribution of allergen-specific $\mathrm{CD} 8^{+} \mathrm{T}$ cells as a function of the applied exogenous allergen concentration, we used a murine model of ovalbumin (OVA)-induced allergic sensitization and aerosol challenge in C57BL/6 mice. This model induces allergen-specific $\mathrm{IgE}$ and $\mathrm{IgG} 1$ as well as airway eosinophilia using a low-dose allergen sensitization protocol. In contrast, using a high-dose sensitization protocol, a modulation of the allergic phenotype is achieved $(26,27)$. An advantage of the murine C57/BL6 model is the possibility to follow OVA-specific $\mathrm{CD} 8^{+} \mathrm{T}$ cell responses by using $\mathrm{H} 2 \mathrm{~Kb}$-multimers, a highly sensitive tool to detect OVAspecific $\mathrm{CD} 8^{+} \mathrm{T}$ cells $(28)$.

In this study, we used this technique and followed allergenspecific $\mathrm{CD} 8^{+} \mathrm{T}$ cells induced in a dose-dependent manner, characterized their phenotype and the various homing and effector organs, and investigated the pathway of cross-presentation that underlies the induction of CD8+ T cells to a soluble antigen. The obtained results show that the number of allergen-specific $\mathrm{CD} 8^{+} \mathrm{T}$ cells in the lung, which is dependent on the allergen sensitization dose, appears to be a critical predictor for the severity of the allergic airway phenotype in mice. Allergen-specific $\mathrm{CD} 8^{+} \mathrm{T}$ cells follow a natural course of kinetics similar to viral infections with contraction after primary allergic sensitization and strong expansion after encountering allergen on airway challenge, thus helping us to understand their physiological role in IgE-mediated allergy under natural or immunotherapeutic conditions.

Some of the results of these studies have been previously reported in the form of an abstract $(29,30)$.

\section{METHODS}

\section{Animals}

Female wild-type C57BL/6 and OT-I mice (C57BL/6 background) mice were obtained from Charles River Laboratories (Wilmington, MA) and Tap1 ${ }^{\text {tm1Arp }}\left(\right.$ TAP1 $^{-1-}$ ) mice (B6.129S2-Tap1tm1Arp/J) from the Jackson Laboratory (Bar Harbor, ME). All mice were housed in the pathogen-free animal facility of the Helmholtz Zentrum München (Germany). The study was conducted under federal guidelines for the use and care of laboratory animals and was approved by the local government (Regierung von Oberbayern) and the Animal Care and Use Committee of the Helmholtz Zentrum München.

\section{Allergen Sensitization and Challenge}

Six- to 10 -week-old mice were sensitized by intraperitoneal injection of $10 \mu \mathrm{g}$ (low dose) or $10 \mathrm{mg}$ (high dose) of OVA (Sigma, Steinheim, Germany) in $2 \mathrm{mg}$ alum (Inject-Alum Pierce, Rockford, IL) on Days 1, 10 , and 26 in $200 \mu$ PBS. The LPS content in the used OVA preparation was $0.07 \mu \mathrm{g} / \mathrm{mg}$ OVA as determined by the limulus amebocyte lysate assay (Lonza, Walkersville, MD). Mice were challenged six times by inhalative exposure to OVA aerosol (6\% in PBS) for 1 hour using a Pari-Boy nebulizer (Pari, Starnberg, Germany) as previously described (31) on Days 82 to 83,85 to 86 , and 88 to 89 . On Day 90, animals were killed. Blood and the lung, liver, mediastinal lymph nodes, bone marrow, spleen, paratracheal lymph nodes, and axillary/inguinal lymph nodes were collected for further analyses. Control animals were sham sensitized and challenged with phosphate buffered saline (PBS) only or with aerosolized OVA ( $6 \%$ in PBS). A modified sensitization and challenge protocol was used for some experiments in which a lower degree of airway inflammation was needed to characterize additive effects (e.g., when using sensitized TAP1 ${ }^{-1-}$ mice). To this end, mice were sensitized by intraperitonal injection of OVA-alum on Days 1 and 7 and challenged three times by exposure to OVA aerosol (1\% in PBS) for 15 minutes on Days 68, 71, and 74 .
In LPS-spiking experiments, LPS (Lonza, Walkersville, MD) from Escherichia coli strain O55:B5 was used.

The description of the methods used for lung functional test, bronchoalveolar lavage (BAL), cytokine analysis, isolation of $\mathrm{CD}^{+}$ $\mathrm{T}$ cells from lung and liver, adoptive cell transfer, cytotoxicity assay, lung histological analysis, determination of plasma antibody titers, and IL concentrations in BAL fluid is provided in the online supplement.

\section{MHC Class I Multimer Staining and Phenotyping of $\mathrm{CD8}^{+} \mathbf{T}$ Cell by Flow Cytometry}

$\mathrm{H} 2-\mathrm{Kb}$ SIINFEKL multimer were purchased from Immunotech (Beckman Coulter, Villepinte, France). Cells were incubated with $\mathrm{H} 2-\mathrm{Kb}$ SIINFEKL multimer and surface marker staining. The following mAbs were used: anti-CD8a (Invitrogen, Karlsruhe, Germany), anti-CD127 (eBioscience, San Diego, CA), anti-CD4, anti-CD3, anti-CD45, antiCD62L, anti-CD25, anti-CD69, anti-CD44, anti-CD154, and anti-Ly6C (BD Bioscience, San Jose, CA). For counting cells, TrueCount (BD Bioscience) was used. Data were acquired on a FACSCalibur or LSRII and were further analyzed with CELLQUEST, FACSDiVa (all BD Bioiscience), and Flowjo V.7.2.2 (Tree Star, Ashland, OR) software.

\section{Statistical Analysis}

Comparisons of groups were performed with a $t$ test, and $P$ values for significance were set to 0.05 . Values for all measurements are expressed as mean \pm SEM.

\section{RESULTS}

\section{Characterization of the Low- and High-Dose Models of OVA Sensitization}

The low-dose sensitization protocol led to an increase in total and OVA-specific plasma IgE (Figures 1A and 1C) and OVAspecific IgG1 (Figure 1B), large numbers of lung infiltrating cells as demonstrated in BAL and lung histology (Figures 1D and $1 \mathrm{~F}$ ), and induction of substantial eosinophilia in BAL of challenged animals representing up to $88 \%$ (mean, $62.7 \pm$ $4.1 \%$ ) of all infiltrating cells (Figure 1E). This low OVA-antigen dose model was further used to analyze the role of allergenspecific $\mathrm{CD}^{+} \mathrm{T}$ cells under conditions that favor allergenspecific $\operatorname{IgE}$ induction and $\operatorname{IgE}$-mediated allergic airway inflammation. In contrast to the low-dose model, we also used $10 \mathrm{mg}$ OVA/alum to sensitize mice in an otherwise identical immunization and challenge setup. The high-dose compared with low-dose condition led to reduced total cellular infiltration in BAL and lung tissue (Figures $1 \mathrm{D}$ and $1 \mathrm{~F}$ ) and lower eosinophilia in BAL (Figure 1E) (mean, $30.4 \pm 3.3 \%$ ) an to a moderate elevation of total and OVA-specific $\operatorname{IgE}$ levels (Figures 1A and 1C) together with a stronger induction of OVA-specific IgG1 levels (Figure 1B). We compared these two protocols in their capacity to induce IL-4 and IL-13 in BAL (see Figure E1 in the online supplement). We correlated both cytokine levels with airway eosinophilia (Figure 1G for IL-4). Our findings demonstrated a positive correlation with more IL4 and airway eosinophilia in the low-dose model (10 $\mu \mathrm{g}$ OVA) as compared with the high-dose model (10 mg OVA), with a clear distinction between the two groups (see correlations separated by group in Fig. E2). Results of lung functional tests comparing the two models are described below (Table 1).

\section{Detection and Phenotype of Allergen-Specific CD8 ${ }^{+} \mathrm{H} 2-\mathrm{Kb}$ SIINFEKL ${ }^{+}$T Cells}

We used $\mathrm{H} 2-\mathrm{Kb}$ SIINFEKL-multimers to follow allergenspecific $\mathrm{CD}^{+} \mathrm{T}$ cells in the low-dose and the high-dose OVA models. We identified a clear difference in the total number of $\mathrm{CD}^{+}$and $\mathrm{CD}^{+} \mathrm{T}$ cells, whereas the total cell number of $\mathrm{CD}^{+} \mathrm{T}$ cells showed no difference. Although we found no differences in the amount of total CD8 T cells between the low- 
A
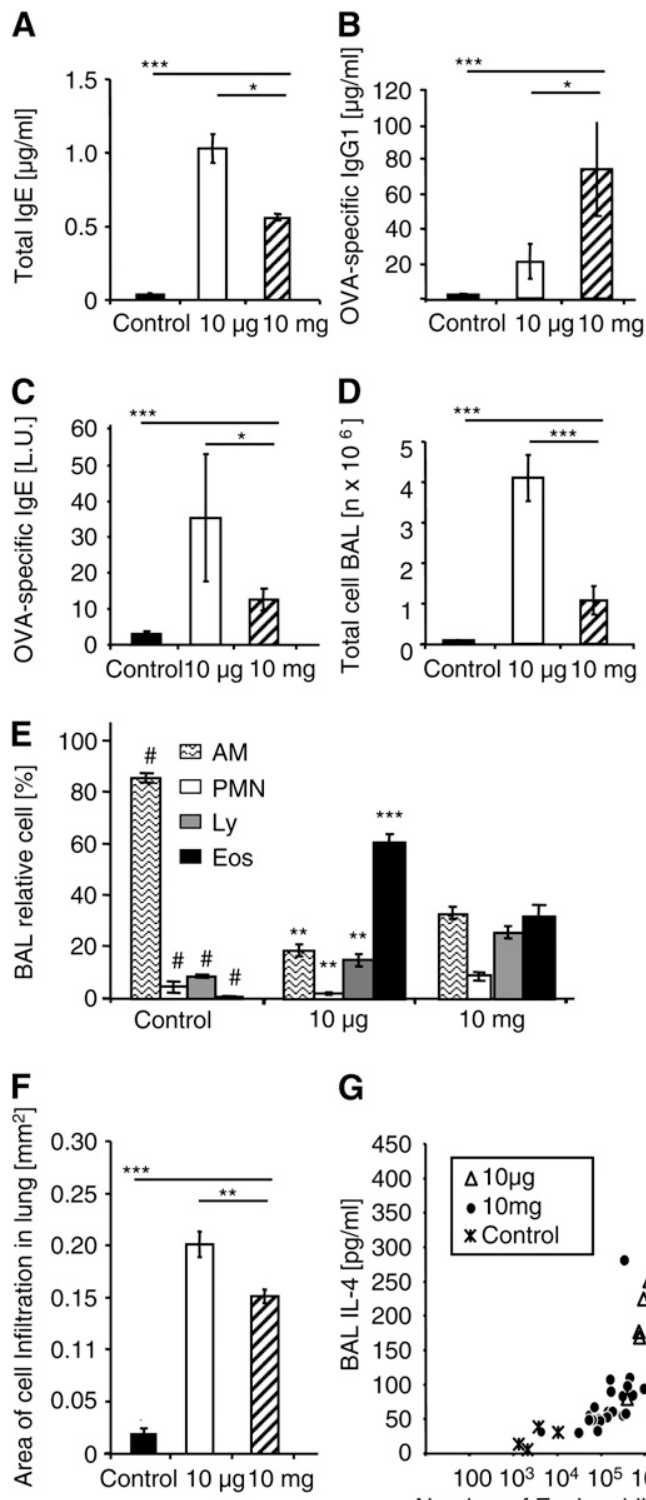

G

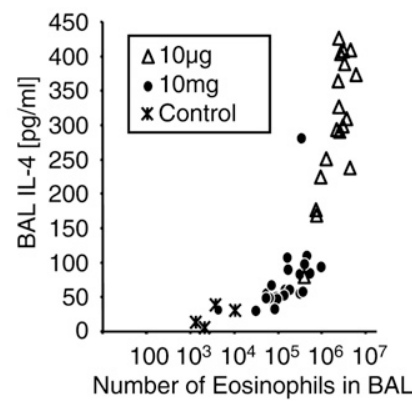

Figure 1. Comparative analysis of control mice with mice sensitized using the low-dose ovalbumin (OVA) protocol (10 $\mu \mathrm{g}$ OVA) or the high-dose protocol (10 mg OVA). Control mice were sensitized with phosphate-buffered saline (PBS) and challenged with aerosolized OVA. Sensitized mice received OVA intraperitoneally on Days 1,10 , and 26 and were challenged with OVA aerosol on Days 82 to 83,85 to 86 , and 88 to 89 . Specimens were analyzed 24 hours after the last challenge (Day 90). (A) Plasma total IgE. (B) OVA-specific IgG1. (C) OVA-specific lgE. (D) Analysis of bronchoalveolar lavage (BAL) total cell number. $(D)$ Analysis relative number of eosinophils. $(F)$ Histological score of the area of lung inflammation. $(G)$ The values of bronchoalveolar lavage (BAL) eosinophilia were correlated to IL-4 production in BAL fluid. AM = alveolar macrophage; Eos = eosinophils; Ly = lymphocyte; $\mathrm{PMN}=$ polymorphonuclear granulocyte (neutrophils). ${ }^{*} P<0.05$; ${ }^{* *} P<0.01$; ${ }^{\star \star *} P<$ $0.001 ;{ }^{\#} P<0.01$ compared with other groups ( $n \geqslant 5$ per group).

and high-dose protocols in BAL, the activation of the CD8a ${ }^{+}$ $\mathrm{T}$ cells shown by the expression of $\mathrm{CD} 62 \mathrm{~L}^{+}$was significantly higher in the high-dose protocol (Figure E3). The amount of $\mathrm{CD} \mathrm{a}^{+}, \mathrm{H} 2-\mathrm{Kb}$ SIINFEKL-multimer ${ }^{+} \mathrm{T}$ cells was clearly higher in the high-dose OVA protocol, which was even more pronounced when $\mathrm{CD}_{8} \mathrm{a}^{+} \mathrm{H} 2-\mathrm{Kb}$ SIINFEKL-multimers were costained with the activation marker CD62L (Figures 2A and
2C). The significantly decreased cell number of $\mathrm{CD}^{+}{ }^{+} \mathrm{T}$ cells in the high-dose OVA model was corroborated by a lower degree of intracellular activation marker staining with CD154 in CD4 ${ }^{+}$ $\mathrm{T}$ cells (32) in the lungs (Figure $2 \mathrm{~B}$ ). Staining of BAL CD4 T cells for Foxp3 ${ }^{+} \mathrm{CD} 25^{+}$revealed a higher number of Foxp3+ regulatory $\mathrm{T}$ cells in the low-dose protocol (Fig. E4).

We found allergen-specific $\mathrm{CD}^{+} \mathrm{H} 2-\mathrm{Kb}$ SIINFEKL ${ }^{+} \mathrm{T}$ cells also in peripheral blood, although to a lesser degree than in BAL, and in lungs 24 hours after the last aerosol-challenge, whereas no allergen-specific $\mathrm{CD}^{+} \mathrm{H} 2-\mathrm{Kb}^{+}$SINFEKL ${ }^{+} \mathrm{T}$ cells were found in control mice exposed to OVA-aerosol challenge (Figure 3A). We characterized the phenotype of the allergen-specific $\mathrm{CD}^{+} \mathrm{T}$ cells infiltrating lung tissue. These experiments revealed that in the low-dose and the high-dose OVA models, MHC multimerpositive cells stained $\mathrm{CD}_{2} \mathrm{~L}^{-}, \mathrm{CD} 25^{+/-}, \mathrm{CD} 44^{+}, \mathrm{CD} 127^{+/-}$, $\mathrm{CD} 9^{+}$, and $\mathrm{Ly}_{6 \mathrm{C}} \mathrm{C}^{+-}$and identified the majority of cells corresponding to an activated effector type of $\mathrm{CD} 8^{+} \mathrm{T}$ cells (33-37). Figure $3 \mathrm{~B}$ gives an example of the typical staining pattern obtained with these phenotypic markers in mice sensitized according to the high-dose OVA model.

To exclude the possibility that the observed increased induction of allergen-specific $\mathrm{CD}^{+}{ }^{+} \mathrm{H} 2-\mathrm{Kb}$ SIINFEKL ${ }^{+} \mathrm{T}$ cells in the high-dose protocol was associated with a higher degree of LPS contamination within the OVA preparations, LPS contents were measured, and the amount of OVA used in the low-dose protocol was spiked with an LPS dose found in the high-dose protocol. We observed no significant differences between the low-dose and the "low dose + additional LPS" protocols (Figure E5).

\section{In Vivo Cytotoxicity of Allergen-specific $\mathrm{CD8}^{+} \mathrm{H} 2-\mathrm{Kb}$ SIINFEKL ${ }^{+}$T Cells}

The functional in vivo cytotoxic potential of the induced allergen-specific $\mathrm{CD}^{+} \mathrm{T}$ cells was tested using SIINFEKLloaded target cells, which were labeled with high concentrations of carboxyfluorescein succinimidyl ester (CFSE) and an otherwise identical SIINFEKL-negative target cell population, which was labeled with low concentrations of CFSE. Adoptive transfer of the CFSE-labeled cells into OVA-sensitized recipient mice allowed us to quantify the cytotoxic activity of allergen-specific $\mathrm{CD}^{+} \mathrm{T}$ cells by determining the loss of SIINFEKL-positive target cells labeled with high concentrations of CFSE dye (Figure 4A). This experiment clearly showed an in vivo cytotoxic potential of induced OVA-specific $\mathrm{CD}^{+} \mathrm{T}$ cells with a time-dependent mean in vivo killing of $46 \%$ (range, $40-50 \%$ ) at 15 hours and $69 \%$ (range, $57-80 \%$ ) at 48 hours in the lowdose protocol (10 $\mu \mathrm{g}$ OVA) and $62 \%$ (range, 51-72\%) at 15 hours and $86 \%$ (range, $71-93 \%$ ) at 48 hours in the highdose protocol (10 mg OVA) (Figure 4B). At all time points, OVA-specific $\mathrm{CD}^{+} \mathrm{T}$ cells induced in the high-dose model displayed a higher cytotoxic capacity as compared with cells induced in the low-dose allergy model. We cannot state if the higher cytotoxic potential is due to the increased number of SIINFEKL-specific CD8-T cells or due to an increased killing potential of these cells.

\section{Kinetics of Allergen-specific CD8 ${ }^{+}$T Cells}

To analyze the kinetics of allergen-specific $\mathrm{CD}^{+} \mathrm{T}$ cell, we focused on the high-dose OVA sensitization model. $\mathrm{H} 2-\mathrm{Kb}$ SIINFEKL multimer staining of allergen-specific CD8 ${ }^{+} \mathrm{T}$ cells in PBMCs showed a moderate increase in blood over time, ranging from $0.05 \%$ to a peak of $0.4 \%$ MHC multimer-positive $\mathrm{CD}^{+} \mathrm{T}$ cells among all $\mathrm{CD} 8^{+} \mathrm{T}$ cells, with a clear maximum during allergen rechallenge (up to $0.8 \%$ ), followed by a reduction of allergen-specific $\mathrm{CD}^{+} \mathrm{T}$ cells immediately after the final OVA-aerosol exposure. Control animals did not show any 
TABLE 1. LUNG FUNCTION TESTS*

\begin{tabular}{lcccc}
\hline & Control & $\begin{array}{c}\text { TAP1 } \\
(10 \mu g \text { OVA })\end{array}$ & $\begin{array}{c}\text { C57BL/6 } \\
(10 \mu g \text { OVA })\end{array}$ & $\begin{array}{c}\text { C57BL/6 } \\
(10 m g \text { OVA })\end{array}$ \\
\hline $\mathrm{TLC}, \mu \mathrm{l}$ & $1,322 \pm 147$ & $1,186 \pm 170$ & $1,118 \pm 168^{\dagger}$ & $1,228 \pm 97$ \\
$\mathrm{VD}, \mu \mathrm{l}$ & $253.2 \pm 9.0$ & $253.8 \pm 10.3$ & $242.4 \pm 15.5$ & $258.4 \pm 9.2^{\ddagger}$ \\
$\mathrm{R}, \mathrm{cm} \mathrm{H} \mathrm{H}_{2} \mathrm{O} / \mathrm{ml} / \mathrm{s}$ & $0.56 \pm 0.07$ & $0.64 \pm 0.13$ & $0.76 \pm 0.23^{\dagger}$ & $0.56 \pm 0.08^{\ddagger}$ \\
$\mathrm{sR}, \mathrm{cm} \mathrm{H} \mathrm{H}_{2} \mathrm{O} / \mathrm{s}$ & $0.73 \pm 0.08$ & $0.75 \pm 0.10$ & $0.83 \pm 0.20$ & $0.69 \pm 0.09$ \\
$\mathrm{C}, \mu \mathrm{l} / \mathrm{cm} \mathrm{H}_{2} \mathrm{O}$ & $62.1 \pm 9.0$ & $63.0 \pm 9.5$ & $56.9 \pm 9.4$ & $63.1 \pm 3.2$ \\
$\mathrm{C}_{\mathrm{Dyn}, \mu \mathrm{l} / \mathrm{cm} \mathrm{H} \mathrm{H}_{2} \mathrm{O}}$ & $43.1 \pm 6.0$ & $40.8 \pm 8.6$ & $36.3 \pm 7.5$ & $41.9 \pm 3.9$ \\
$\mathrm{DL} \mathrm{CO}, \mu \mathrm{mol} / \mathrm{min} / \mathrm{hPa}$ & $13.0 \pm 1.9$ & $9.6 \pm 2.0^{* \star}$ & $9.6 \pm 2.1^{\S}$ & $11.2 \pm 0.9^{\dagger}$ \\
\hline
\end{tabular}

Definition of abbreviations: $C=$ quasi-static compliance of the respiratory system; OVA $=$ ovalbumin; $C_{\text {Dyn }}=$ dynamic compliances at a breathing rate of $130 / \mathrm{min} ; \mathrm{R}=$ respiratory system resistance; $\mathrm{sR}=$ specific resistance.

* Lung function tests in intubated/mechanically ventilated animals performed 24 hours after the last OVA challenge in nonsensitized (control), OVA-sensitized TAP1 ${ }^{-1-}$, and in OVA-sensitized wild-type C57BL/6 mice with low or high allergen doses (10 $\mu \mathrm{g}$ and $10 \mathrm{mg}$ OVA, respectively). Data are expressed as mean \pm SD; $\mathrm{n}=5-8$ per group.

$+P<0.05$ vs. control;

${ }^{\ddagger} P<0.05$ vs. $10 \mu \mathrm{g}$ OVA, and

$\S p \leqslant 0.01$ vs. control.

presence of MHC multimer-positive cells at all time points (Figure 5A). The analysis in lung tissue revealed a dramatic increase of $\mathrm{MHC}$ multimer-positive, $\mathrm{CD} 62 \mathrm{~L}^{-} \mathrm{CD}^{+} \mathrm{T}$ cells at the time of the last rechallenge with OVA-aerosol (Figure 5B). The number of allergen-specific $\mathrm{CD}^{+} \mathrm{T}$ cells rapidly dropped thereafter but remained stable between 3 and $5 \%$ over several weeks, suggesting an organ-specific memory pool of allergenspecific $\mathrm{CD}^{+} \mathrm{T}$ cells (Figure $5 \mathrm{~B}$ ).

Next, we screened for the cytokine phenotype of lung infiltrating allergen-specific $\mathrm{CD} 8^{+} \mathrm{T}$ cells. This analysis revealed a clear production of IFN- $\gamma$ by SIINFEKL-stimulated $\mathrm{CD}^{+} \mathrm{T}$ cells but no production of IL-4 (Figure 5C), IL-10, IL-5, or IL13 (data not shown).

\section{Organ Distribution of Allergen-specific CD8 ${ }^{+}$T Cells}

Blood and lung/BAL analyses showed high expansion of MHC multimer-positive $\mathrm{CD}^{+} \mathrm{T}$ cells in the lung and in the BAL cells but showed low numbers within the peripheral blood (Figure 3A, 5A, 5B, and 5D). In addition to the effector organ lung and the peripheral blood, we analyzed the distribution of allergen-specific $\mathrm{CD}^{+} \mathrm{H} 2-\mathrm{Kb}^{+}$SIINFEKL ${ }^{+} \mathrm{T}$ cells in several lymphatic organs and the liver to gain information on sites of proliferation and/or activation of these cells. We found high numbers of activated $\left(\mathrm{CD}^{2} \mathrm{~L}^{-}\right) \mathrm{CD}^{+} \mathrm{H} 2-\mathrm{Kb}$ SIINFEKL ${ }^{+} \mathrm{T}$ cells in lungs and BAL but also in the liver (up to $10 \%$ ), whereas bone marrow, spleen, paratracheal, and axillary and inguinal lymph nodes showed percentages below $2 \%$ of allergen-specific $\mathrm{CD}^{+} \mathrm{T}$ cells (Figure 5D). The lymphatic sites with the highest number of $\mathrm{CD}^{+} \mathrm{H} 2-\mathrm{Kb}$ SIINFEKL ${ }^{+} \mathrm{T}$ cells were the mediastinal lymph nodes $(2.6 \%)$. Mediastinal lymph nodes also harbored the highest proportion of $\mathrm{CD} 62 \mathrm{~L}^{+}$ $\mathrm{H} 2-\mathrm{Kb}$ SIINFEKL ${ }^{+} \mathrm{CD}^{+}{ }^{+} \mathrm{T}$ cells $(28 \%)$, whereas in all other tissues, only a minority of $\mathrm{H} 2-\mathrm{Kb} \mathrm{SIINFEKL}{ }^{+} \mathrm{CD}^{+} \mathrm{T}$ cells was CD62L $\mathrm{L}^{+}$(Figure 5D).

\section{Recruitment and In Situ Proliferation of Allergen-specific CD8 $^{+}$T Cells}

Based on the evidence obtained so far that in the course of sensitization and rechallenge allergen-specific $\mathrm{CD}^{+} \mathrm{T}$ cells are found in increasing numbers in the lungs and BAL cells, we wanted to know whether this increase was due to an enhanced recruitment of this cell type (which had been proliferating, e.g., in lymph nodes) or if there was proliferation of $\mathrm{CD}^{+} \mathrm{T}$ cells residing in the lungs after allergen exposure. Therefore, purified CD $8^{+} \mathrm{T}$ cells from OT-I mice were labeled with CFSE and transferred into naive C57/BL6 mice before these chimeras were challenged by OVA aerosol exposure. This experiment showed that before allergen challenge there was a population of OT-I cells that had migrated to the lungs, most probably due to random migration (Figure 6A). After aerosol challenge, the cells rapidly started proliferating so that after the third challenge the majority of cells had undergone several divisions in lung tissue (Figure 6B). In contrast, no OTI cells were detectable in BAL of control mice, whereas after OVA-aerosol challenge large numbers of proliferating OT-I cells were found in BAL (Figures 6A and 6B). The result of this experiment suggests that recruitment into the effector organ and proliferation together with transbronchial migration upon antigen encounter occur.
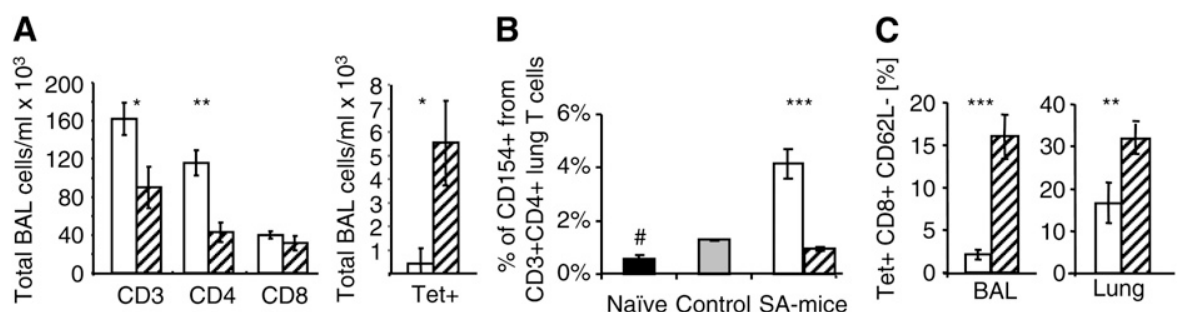

Figure 2. Differential cell distribution in the low- and high-dose ovalbumin (OVA) models in bronchoalveolar lavage (BAL) and lung. Mice were sensitized intraperitoneally with OVA on Days 1, 10, and 26 and challenged with OVA aerosol on Days 82 to 83,85 to 86 , and 88 to 89 (SA mice). (A) Detection and counting of $\mathrm{CD}^{+}, \mathrm{CD}^{+}, \mathrm{CD}^{+}$, and $\mathrm{CD}^{+} \mathrm{H} 2-\mathrm{Kb}$ SIINFEKL-specific T cells (Tet + ) in BAL after the final OVA-aerosol challenge. Number of cells is calculated from $1 \mathrm{ml}$ of BAL fluid. (B) Intracellular staining of CD154 in CD4 ${ }^{+} \mathrm{T}$ cells from lung after

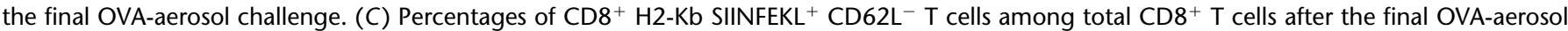
challenge. Open bars, $10 \mu \mathrm{g}$ OVA (low-dose protocol); hatched bars, $10 \mathrm{mg}$ OVA (high-dose protocol). Control = mice sensitized with phosphate buffered saline and challenged with aerosolized OVA. Naive $=$ untreated mice. $\mathrm{SA}=$ mice sensitized and challenged with $\mathrm{OVA}$. ${ }^{*} P<0.05,{ }^{* *} P<$ $0.01,{ }^{* * *} P<0.001$, and ${ }^{\#} P<0.01$ compared with other groups. 


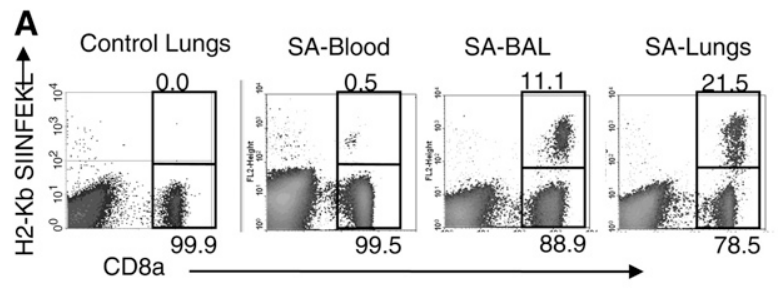

B CD8+ T cells in SA-Lungs

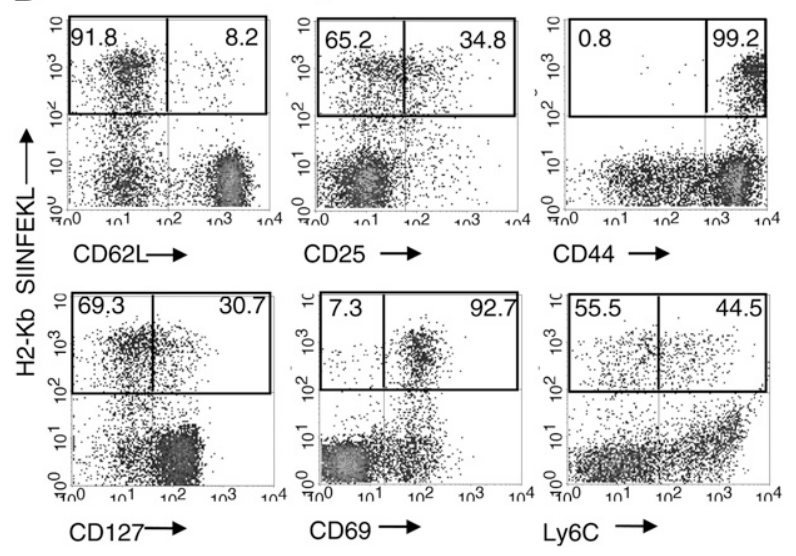

Figure 3. Detection and phenotype of $\mathrm{CD} 8{ }^{+} \mathrm{H} 2-\mathrm{Kb}$ SIINFEKL-specific $\mathrm{T}$ cells. Mice were sensitized intraperitoneally with $10 \mathrm{mg}$ ovalbumin (OVA) on Days 1, 10, and 26 and challenged with OVA aerosol on Days 82 to 83,85 to 86 , and 88 to 89 . (A) Percentages of $\mathrm{CD}^{+}{ }^{+} \mathrm{H} 2-\mathrm{Kb}$ SIINFEKL ${ }^{+} \mathrm{T}$ cells among total CD8 ${ }^{+} \mathrm{T}$ cells after the final OVA-aerosol challenge in lungs of control animals (sensitized with phosphate buffered saline followed by OVA-aerosol challenge) or of animals that received OVA sensitization and subsequent OVA-aerosol challenge (SA). $\mathrm{CD}^{+} \mathrm{H} 2-\mathrm{Kb}$ SIINFEKL ${ }^{+} \mathrm{T}$ cells where analyzed in blood (SAblood), bronchoalveolar lavage (BAL) (SA-BAL), and lung tissue (SAlungs). (B) Animals that received OVA sensitization and subsequent OVA-aerosol challenge and their phenotypic surface marker expression of lung $\mathrm{CD}^{+} \mathrm{H} 2-\mathrm{Kb}$ SIINFEKL ${ }^{+} \mathrm{T}$ cells 24 hours after the final OVAaerosol challenge. The percentage of cells in each quadrant was calculated by gating $\mathrm{CD}^{+} \mathrm{H} 2-\mathrm{Kb}$ SIINFEKL ${ }^{+} \mathrm{T}$ cells.

\section{Allergen-specific CD8 ${ }^{+}$T Cells in the Lungs Are Induced by a TAP-dependent Pathway}

To test whether cross-presentation plays a role in allergenspecific $\mathrm{CD}^{+} \mathrm{T}$-cell proliferation after OVA-aerosol exposure, we used TAP1 ${ }^{-1-}$ mice on the C57BL/6 background, which are deficient in the proper translocation of antigen-derived peptides onto empty MHC-I molecules residing in the endoplasmic reticulum. In an identical set-up as in the proliferation experiments (Figures 6A and 6B), CFSE-labeled OT-I cells $(\sim 3 \times$ $10^{6}$ enriched $\mathrm{CD}^{+}$cells) were transferred into $\mathrm{TAP}^{-1-}$ mice, and animals were challenged with OVA-aerosol. OT-I CD8 ${ }^{+} \mathrm{T}$ cells migrated into the lungs of TAP1 ${ }^{-1-}$ mice (Figure $6 \mathrm{C}$ ) but were not capable of proliferating upon OVA-aerosol challenge in contrast to wild-type C57BL/6 mice (Figure 6B).

\section{Allergen-specific CD8 ${ }^{+}$T Cells and the Degree of the Pulmonary Inflammatory Response}

Because several reports that relied on the depletion of $\mathrm{CD}^{+} \mathrm{T}$ cells in the murine model have shown contradictory roles for $\mathrm{CD}^{+} \mathrm{T}$ cells in IgE-mediated allergy $(5,14,15,38)$, we evaluated the natural course of the low-dose and the high-dose OVA models for allergic sensitization with multiple correlations comparing the generation of $\mathrm{CD}^{+} \mathrm{H} 2-\mathrm{Kb} \mathrm{SIINFEKL}^{+} \mathrm{T}$ cells with markers of activation and airway inflammation. In
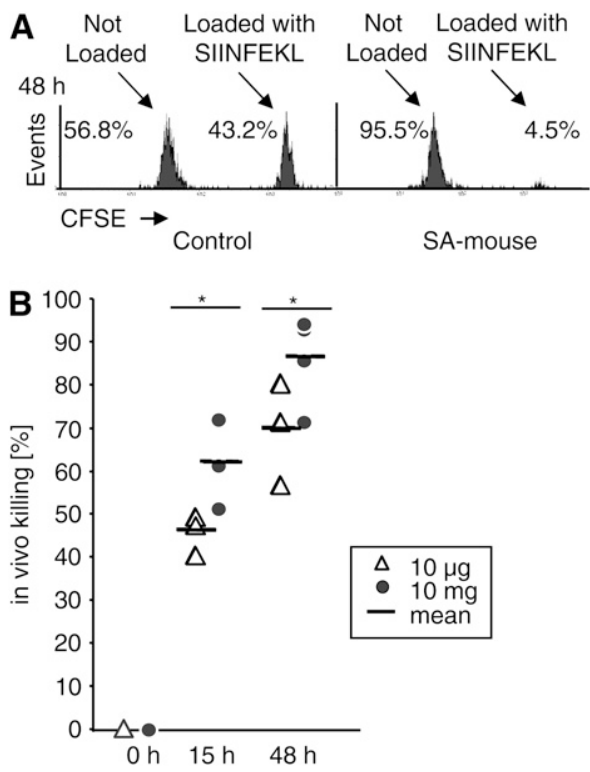

Figure 4. Dependency of the induction of cytotoxicity on the antigen dose used in the sensitization phase. Mice were sensitized intraperitoneally with ovalbumin (OVA) on Days 1, 10, and 26 and challenged with OVA aerosol on Days 82 to 83,85 to 86 , and 88 to 89 (SA-mice). Cytotoxic potential was demonstrated by in vivo lysis of highly carboxyfluorescein succinimidyl ester (CFSE)-labeled SIINFEKL-loaded splenocytes in comparison to unloaded low CFSE-labeled splenocytes. $(A)$ Representative experiment of one control and an SA mouse after 48 hours. (B) Time and dose dependency of the in vivo cytotoxic potential of allergen-specific $\mathrm{CD}^{+} \mathrm{H} 2-\mathrm{Kb}$ SIINFEKL ${ }^{+} \mathrm{T}$ cells using splenocytes differentially labeled with CFSE, either SIINFEKL loaded or unloaded. Cytotoxicity was recorded by FACS analysis after 0,15 , and 48 hours. Black dots indicate individual animals sensitized with high-dose OVA $(10 \mathrm{mg})$; open triangles indicate animals sensitized with low-dose OVA $(10 \mu \mathrm{g})$. The line represents the mean of each group. ${ }^{*} P<0.05$.

BAL and in cells infiltrating the lungs, more than $90 \%$ of the $\mathrm{CD}^{+} \mathrm{H} 2-\mathrm{Kb}$ SIINFEKL ${ }^{+} \mathrm{T}$ cells showed the phenotype of activated cells as defined by loss of CD62L (see Figures 3B and 4D). Consequently, we observed a positive correlation of activated $\mathrm{CD}^{+} \mathrm{T}$ cells (as defined by the loss of CD62L expression) and $\mathrm{CD} 8^{+} \mathrm{H} 2-\mathrm{Kb}$ SIINFEKL ${ }^{+} \mathrm{T}$ cells with allergen dose. Higher numbers of $\mathrm{CD}^{+} \mathrm{H} 2-\mathrm{Kb}$ SIINFEKL ${ }^{+} \mathrm{T}$ cells were induced by the high-dose protocol (closed dots) as compared with the low-dose group (open triangles) (Figure 7A). The proportion of $\mathrm{CD}^{+} \mathrm{H} 2-\mathrm{Kb}$ SIINFEKL ${ }^{+} \mathrm{T}$ cells detected in BAL was inversely correlated to the degree of airway eosinophilia, whereby the two dosage groups could be clearly distinguished (Figure 7B). Along the same line, the total number of inflammatory cells detected in BAL after OVAaerosol challenge was negatively correlated with the proportion of infiltrating $\mathrm{CD}^{+} \mathrm{H} 2-\mathrm{Kb}$ SIINFEKL ${ }^{+} \mathrm{T}$ cells (Figure 7C) (see correlations separated by group in Fig. E6). Thus, the more allergen-specific and activated $\mathrm{CD}^{+} \mathrm{H} 2-\mathrm{Kb}$ SIINFEKL $^{+} \mathrm{T}$ cells infiltrate the lung, the less eosinophilia and total cell infiltration is found in BAL. This analysis resulted in a clearcut distinction of the two groups receiving the low-dose or the high-dose OVA sensitization protocol.

\section{TAP1-deficient Mice Show an Enhanced Allergic Phenotype}

To evaluate a mouse model with defective cross presentation pathway and a consequent lack of induction of OVA-specific $\mathrm{CD}^{+} \mathrm{T}$ cells, we included $\mathrm{TAP}^{-1-}$ mice in the low-dose 
A

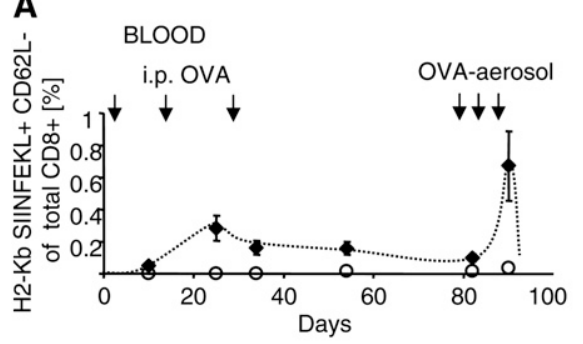

B
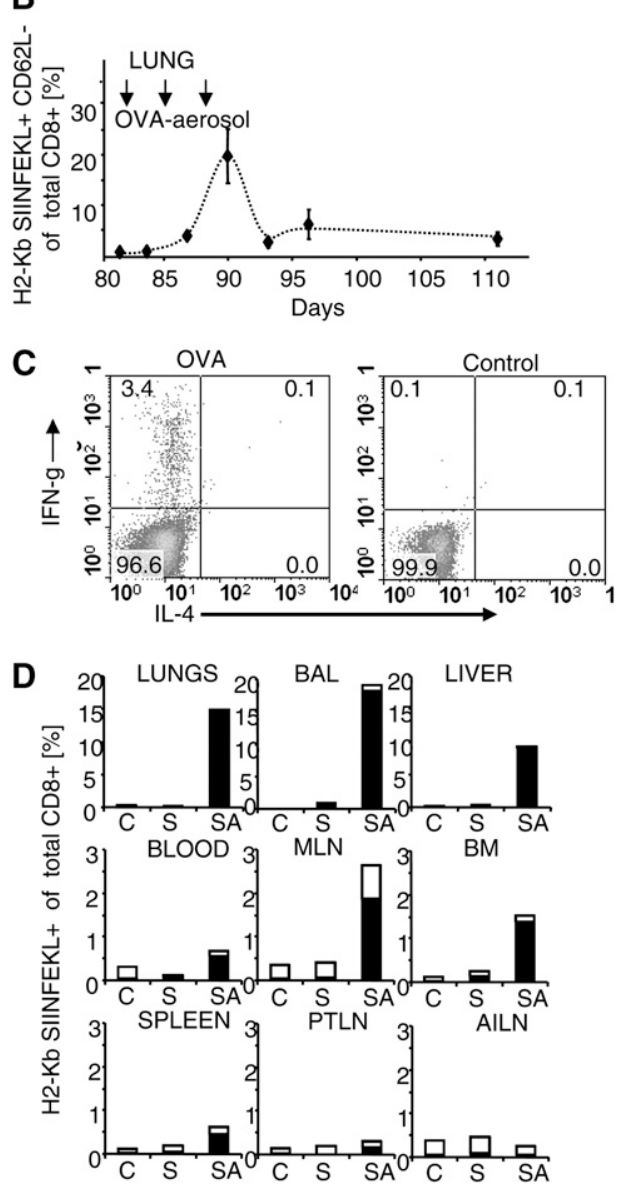

allergen sensitization and challenge model. This model avoids the known limitation of additionally depleting $\mathrm{CD} 8^{+}$dendritic cells as is the case when using anti-CD8 antibody (7). Using this approach, TAP1 $1^{-1-}$ mice compared with wild-type BL6 mice showed significantly higher total numbers of inflammatory cells infiltrating the airways together with increased levels of total $\operatorname{IgE}$ after allergen challenge, suggesting a beneficial role of allergen-specific $\mathrm{CD}^{+} \mathrm{T}$ cells in the control of allergic $\operatorname{IgE}$ responses and airway inflammation (Figures $8 \mathrm{~A}$ and $8 \mathrm{~B}$ ). $\mathrm{TAP}^{-1-}$ mice showed a comparable high degree of eosinophilia in the airways $(\sim 72 \%)$ as compared with wild-type BL6 mice in the low-dose OVA protocol (Figure 8C) while compensating for the lack of $\mathrm{CD} 8^{+} \mathrm{T}$ cells by higher numbers of infiltrating $\mathrm{CD}^{+}{ }^{+} \mathrm{T}$ cells and $\mathrm{NK} 1.1^{+}$cells (data not shown).

\section{Lung Function Tests}

Lung function tests performed 24 hours after the last OVA challenge showed significantly increased respiratory system resistance $(\mathrm{R})$ in low-dose-sensitized animals compared with control nonsensitized animals and with high-dose-sensitized
Figure 5. Kinetics, organ distribution, and intracellular cytokine phenotype of $\mathrm{CD}^{+}{ }^{+} \mathrm{H} 2-\mathrm{Kb}$ SIINFEKL ${ }^{+} \mathrm{T}$ cells in blood and lungs from mice sensitized with high-dose ovalbumin (OVA) $(10 \mathrm{mg})$. OVA-specific $\mathrm{CD}^{+} \mathrm{T}$ cells expand and contract after intraperitoneal application of OVA-alum and after OVA-aerosol challenge as visualized by $\mathrm{H} 2-\mathrm{Kb}$ MHC multimer staining. (A) Percentages of $\mathrm{CD}^{+} \mathrm{H} 2-\mathrm{Kb}$ SIINFEKL ${ }^{+}$ $\mathrm{CD}^{2} \mathrm{~L}^{-} \mathrm{T}$ cells among total $\mathrm{CD}^{+}{ }^{+} \mathrm{T}$ cells in peripheral blood at different time points. Arrows indicate time points of intraperitoneal sensitization and time points of OVA-aerosol challenge (Days 82-83, 85-86, and 88-89). Closed diamonds represent the group of mice sensitized intraperitoneally with OVA-alum (mean values $\pm S D ; n=5$ ). Open circles represent the control group of mice injected with phosphate buffered saline (PBS) $(n=5)$. (B) Percentages of $\mathrm{CD}^{+} \mathrm{H} 2-\mathrm{Kb}$ SIINFEKL ${ }^{+} \mathrm{CD}^{2} \mathrm{~L}^{-} \mathrm{T}$ cells among total $\mathrm{CD}^{+} \mathrm{T}$ cells in lungs at different time points after OVA-aerosol challenge. Arrows indicate time points of OVA-aerosol challenge (Days 82-83, 85-86, and 88-89) (mean values $\pm \mathrm{SD} ; \mathrm{n}=3$ ). (C) Intracellular cytokine profile (IFN- $\gamma$ and IL-4) of lung $\mathrm{CD}^{+} \mathrm{T}$ cells from a representative mouse sensitized intraperitoneal with $10 \mathrm{mg}$ OVA followed by OVA-aerosol challenge. Cells were collected 24 hours after the last airway challenge and restimulated in vitro with $1 \mu \mathrm{g} / \mathrm{ml}$ SIINFEKL peptide for 6 hours. (D) Organ distribution in a representative mouse sensitized intraperitoneally with $10 \mathrm{mg}$ OVA followed by OVA-aerosol challenge. $\mathrm{CD}^{+} \mathrm{H} 2-\mathrm{Kb}$ SIINFEKL ${ }^{+} \mathrm{T}$ cells were enumerated in lungs, bronchoalveolar lavage $(B A L)$, liver, blood, mediastinal lymph node $(M L N)$, bone marrow (BM), spleen, paratracheal lymph node (PTLN), and axillary/inguinal lymph node (AILN) 24 hours after the last airway challenge. The filled (black) part of the columns represents the $\mathrm{CD}^{2} 2 \mathrm{~L}^{-}$fraction of total $\mathrm{CD}^{+} \mathrm{H}^{-}-\mathrm{Kb}$ SIINFEKL ${ }^{+} \mathrm{T}$ cells. $\mathrm{C}=$ control mouse; $\mathrm{S}=$ OVA-sensitized mouse; $\mathrm{SA}=\mathrm{OVA}$-sensitized and airway-challenged mouse.

animals (low dose vs. control, ${ }^{*} P<0.05$; low dose vs. high dose, ${ }^{\#} P<0.05$; Table 1$)$. The $\mathrm{R}$ value for $\mathrm{TAP} 1^{-/-}$was in between the values for control mice and low-dose-challenged mice but was not significantly different from either of the groups. Specific resistance assessed to correct for the observed differences in TLC between control and low-dose mice did not significantly differ between groups but, similarly to $\mathrm{R}$, was found to be highest in low-dose-sensitized mice. No significant difference in static and dynamic compliance was evaluated in any of the groups. A notable reduction in $\mathrm{DL}_{\mathrm{CO}}$ was detected in sensitized (10 $\mu \mathrm{g}$ and $10 \mathrm{mg}$ OVA) and TAP1 $1^{-1-}$ mice compared with control $\left(* * P \leqslant 0.01\right.$ control versus $10 \mu \mathrm{g}$ OVA and TAP $1^{-1-}$, and $* P<0.05$ vs. $10 \mathrm{mg}$ OVA; Table 1$)$.

\section{DISCUSSION}

We have analyzed the natural course of antigen dose-dependent induction and memory formation of allergen-specific $\mathrm{CD} 8^{+} \mathrm{T}$ cells in a murine model of IgE-mediated allergic sensitization and airway inflammation upon allergen rechallenge. Allergen-specific $\mathrm{CD} 8^{+} \mathrm{T}$ cells were recruited to and specifically activated in the lungs of sensitized animals after allergen-aerosol challenge, a process that was dependent on a functional TAP complex. Due to the experimental setting we used, we cannot rule out the possibility that cells might have also divided in the neighboring lymph nodes and then remigrated to the lungs.

Our study provides new perspectives to the complex question as to whether allergen-specific $\mathrm{CD} 8^{+} \mathrm{T}$ cells are of beneficial or of detrimental effect on allergen-specific IgE regulation and on allergic airway inflammation by investigating antigen dosedependent induction of $\mathrm{CD}^{+} \mathrm{H} 2-\mathrm{Kb}$ SIINFEKL ${ }^{+} \mathrm{T}$ cells in the natural course of allergic sensitization and allergen-aerosol challenge. We found an allergen dose-dependent induction and infiltration of activated $\mathrm{CD}^{+}{ }^{+} \mathrm{H} 2-\mathrm{Kb}$ SIINFEKL ${ }^{+} \mathrm{T}$ cells to the lungs, which predominantly were of the effector phenotype. 
A
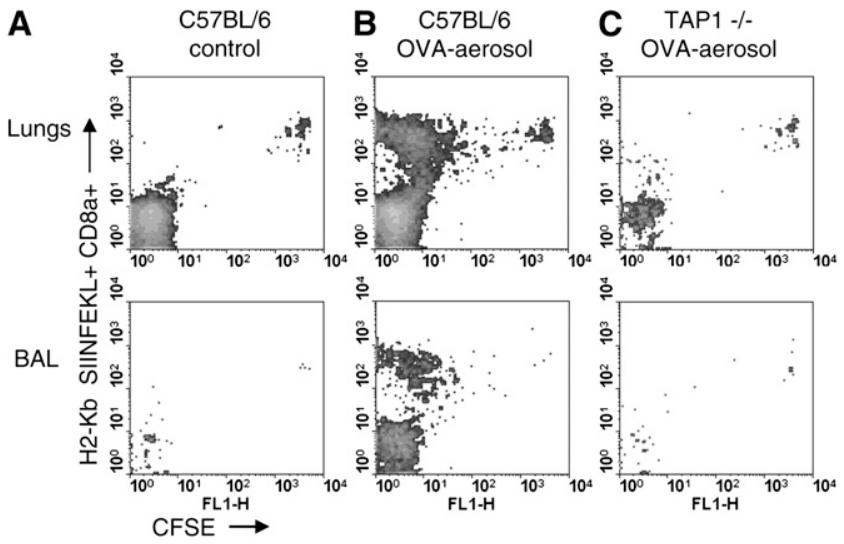

Figure 6. Two groups of $\mathrm{C} 57 \mathrm{BL} / 6$ mice and a group of transgenic TAP1 ${ }^{-1-}$ mice $(n=3)$ were adoptively transferred intravenously with carboxyfluorescein succinimidyl ester (CFSE)-labeled OT-I cells $(\sim 3 \times$ $10^{6}$ purified CD8 ${ }^{+} \mathrm{T}$ cells) 1 day after aerosol challenge was performed. One $\mathrm{C} 57 \mathrm{BL} / 6$ group and the $\mathrm{TAP} 1^{-/-}$group were subsequently exposed to OVA-aerosol challenge; the other C57BL/6 group was exposed to phosphate buffered saline-aerosol challenge (control). Twenty-four hours after the last challenge, animals were killed, and cells from lungs ( $A-C$, upper panel) and bronchoalveolar lavage (BAL) ( $A-C$, lower panel) were harvested. $(A) C 57 \mathrm{BL} / 6$ mice transferred with CFSE-labeled OT-I cells challenged with phosphate buffered saline. (B) C57BL/ 6 mice transferred with CFSE-labeled OT-I cells and exposed for 1 hour on three consecutive days with OVA-aerosol (6\%, w/v). (C) TAP1 ${ }^{-/-}$mice transferred with CFSE-labeled OT-I cells and exposed for 1 hour on three consecutive days with OVA-aerosol $(6 \%, \mathrm{w} / \mathrm{v})$.

One of the most important findings of our study was the dependency of $\mathrm{CD}^{+} \mathrm{H} 2-\mathrm{Kb}$ SIINFEKL ${ }^{+} \mathrm{T}$-cell induction and activation on the OVA-allergen dose used for allergic sensitization and the inverse correlation of these allergen-specific $\mathrm{CD}^{+} \mathrm{T}$ cells with the observed allergic phenotype (Figures 2 and 7). When a low allergen dose of $10 \mu \mathrm{g}$ OVA together with alum adjuvant was injected intraperitoneally for allergic sensitization, high titers of total and allergen-specific $\operatorname{IgE}$ and substantial pulmonary eosinophilia after OVA-aerosol challenge were reproducibly obtained. Lung function testing revealed an increased airway resistance and a decreased gas exchanging capacity 24 hours after the last challenge compared with control as a consequence of airway and peripheral lung inflammation. This model can therefore be considered as an experimental equivalent of IgE-mediated allergic airway inflammation. In contrast, when a high allergen dose of $10 \mathrm{mg}$ OVA together with alum adjuvant was injected, significantly lower titers of total and allergen-specific IgE and significantly reduced airway eosinophilia after OVA-aerosol challenge and only minor alterations in lung function were observed. Compared with the situation in humans, this model most probably represents the situation seen in allergen-specific immunotherapy. The high-dose model, which showed an obvious protective deviation from the Th2 phenotype of the low-dose model (see Figure 1G), was characterized by the induction of significantly higher numbers of activated $\mathrm{CD}^{+} \mathrm{H} 2-\mathrm{Kb}$ SIINFEKL ${ }^{+} \mathrm{T}$ cells in the effector organ lung and the allergen-exposed airways.

The high number of allergen-specific CD8 cells seems to compensate for a lower number of activated CD4 T cells in our model and might therefore be a good marker of protection from type I allergy. Previously, others had demonstrated that $\mathrm{IgE}$ induction and allergic inflammation could be modulated by different sensitizing allergen doses $(26,27)$. However, the Th2 modulating effect of applying higher allergen doses has not

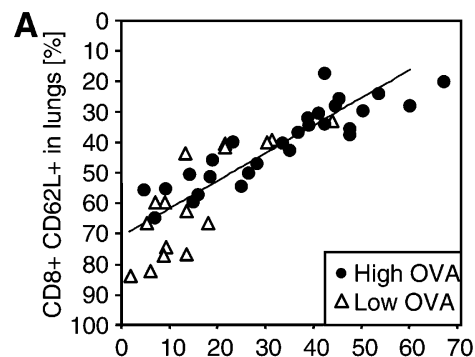

$\mathrm{H} 2-\mathrm{Kb}$ SIINFEKL+ of total CD8+ in lungs [\%]
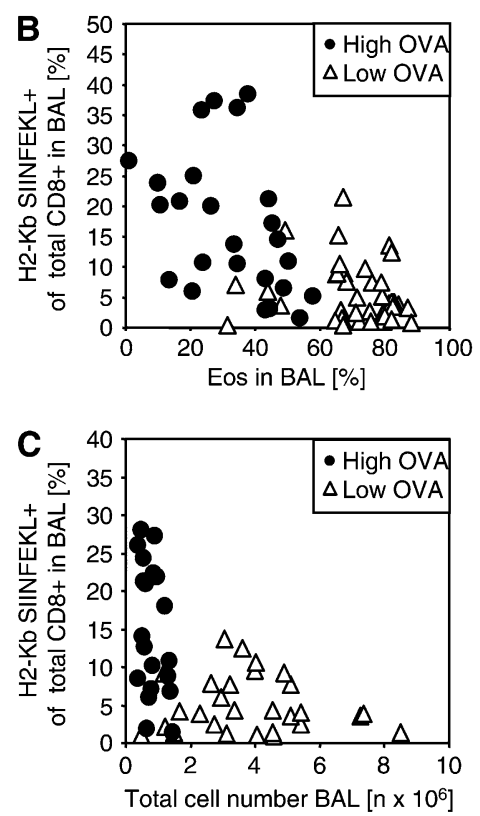

Figure 7. Correlation analysis of all data derived from independent experiments in the high-dose ovalbumin (OVA) model (closed circles) and the low-dose OVA model (open triangles) of allergic sensitization. Mice were sensitized intraperitoneally with $10 \mu \mathrm{gg}$ (low dose) or $10 \mathrm{mg}$ (high dose) OVA on Days 1, 10 , and 26 and challenged with OVA aerosol on Days 82 to 83,85 to 86 , and 88 to 89 . (A) Correlation analysis of the percentage of activated $\mathrm{CD}^{+} \mathrm{T}$ cells $\left(\mathrm{CD} 2 \mathrm{~L}^{-}\right)$and the percentage of $\mathrm{CD}^{+} \mathrm{H} 2-\mathrm{Kb}$ SIINFEKL ${ }^{+} \mathrm{T}$ cells in lung tissue 24 hours after the final OVA-aerosol challenge (total $n=44$ ). (B) Correlation analysis of the percentage of eosinophils and the percentage of $\mathrm{CD}^{+} \mathrm{H} 2-\mathrm{Kb}$ SIINFEKL ${ }^{+}$ $\mathrm{T}$ cells in bronchoalveolar lavage (BAL) 24 hours after the final OVA-aerosol challenge (total $n=68$ ). (C) Correlation analysis of the total number of BAL cells and the percentage of $\mathrm{CD}^{+}{ }^{+} \mathrm{H} 2-\mathrm{Kb}$ SIINFEKL ${ }^{+} \mathrm{T}$ cells 24 hours after the final OVA-aerosol challenge (total $n=64$ ).

been linked to the induction of allergen specific $\mathrm{CD}^{+} \mathrm{T}$ cells. We have also looked for regulatory $\mathrm{T}$ cells as identified by the FoxP3 and CD25 high phenotypes. The numbers of these $\mathrm{T}_{\text {regs }}$ were higher in the BAL of mice undergoing the low-dose protocol with the stronger allergic phenotype. Therefore, it seems unlikely that $\mathrm{T}_{\text {reg }}$ cells had a major impact on the attenuated outcome in the high-dose protocol.

The phenotypic profile of allergen-specific $\mathrm{CD}^{+} \mathrm{T}$ cells induced under both dosage regimens showed no differences with the expression markers tested in this study. However, he numbers of induced allergen-specific $\mathrm{CD}^{+} \mathrm{T}$ cells and the degree of in vivo cytotoxicity were significantly higher with the high-dose OVA model as compared with the low-dose model. The expressed phenotype of these allergen-specific CD8 cells after aerosol challenge closely resembled activated effector $\mathrm{CD}^{+} \mathrm{T}$ cells with up-regulation of CD69 as early T-cell activation marker, reduced expression of the IL-7 receptor CD127, and almost complete down-regulation of CD62L and high expression of CD44 (33-37). Only mediastinal lymph nodes harbored a larger proportion of $\mathrm{CD}^{+} \mathrm{T}$ cells expressing CD62L, indicative of central memory formation (34). The pattern, kinetics, and distribution of $\mathrm{CD}^{+} \mathrm{T}$-cell activation, expansion, and retraction in the course of allergic sensitization and airway inflammation strongly resembles the patterns known for viral defense that have been firmly established in infection and vaccination protocols $(28,39)$ in which a pool of central memory $\mathrm{CD}^{+} \mathrm{T}$ cells persists weeks to months after infection and enters partially in the pool of effector (memory) CD8 ${ }^{+}$ $\mathrm{T}$ cells after repetitive antigen encounters $(37,40)$. 
A

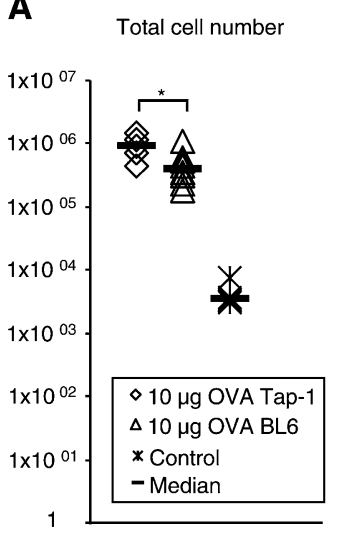

B

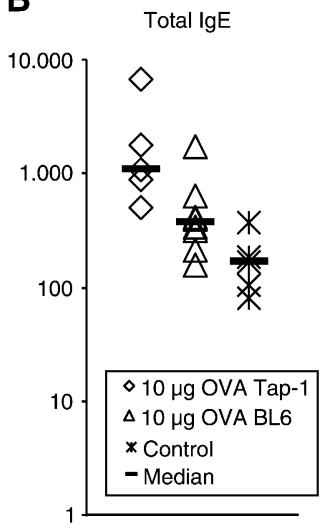

Cosinophilia

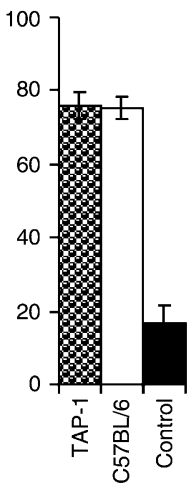

Figure 8. Comparison of airway inflammation and IgE induction using TAP1-/- and wild-type C57BL/6 mice in the low-dose model of allergic sensitization and aerosol challenge. Control mice were not sensitized but received ovalbumin (OVA) aerosol challenge. Mice were analyzed after allergen challenge with OVA aerosol. Shown is the degree of allergic airway inflammation as delineated by $(A)$ the total number of infiltrating cells and $(C)$ eosinophilia in bronchoalveolar lavage (BAL) as well as $(B)$ the levels of total plasma lgE after allergen challenge. The differences between groups were not statistically significant. Mice were sensitized intraperitoneally with $10 \mu \mathrm{g}$ OVA on Days 1 and 7 and challenged with OVA aerosol ( 15 minutes $1 \% \mathrm{w} / \mathrm{v}$ ) on Days 68,71 , and 74. Specimens were analyzed 24 hours after the last challenge $(n=5-8$ mice per group; ${ }^{*} P<0.05$ ).

In both dosage models, apart from the effector organ lungs where antigen is encountered directly by $\mathrm{CD} 8^{+} \mathrm{T}$ cells after OVA-aerosol allergen challenge, significant numbers of $\mathrm{CD}^{+}$ $\mathrm{H} 2-\mathrm{Kb}$ SIINFEKL ${ }^{+} \mathrm{T}$ cells were found in the liver after allergen challenge (Figure 5D). This implies that a significant proportion of activated $\mathrm{CD} 8^{+} \mathrm{T}$ cells, after regressing from the lungs, are preferentially retained in the liver as an ultimate site for activated $\mathrm{CD}^{+}$effector T-cell migration. We cannot explain the physiological relevance of high numbers of $\mathrm{CD} 8^{+}$ $\mathrm{H} 2-\mathrm{Kb}$ SIINFEKL ${ }^{+} \mathrm{T}$ cells within liver tissue after allergen challenge. One contributing factor could be the route of allergic sensitization through intraperitoneal injection of OVA allergen. Furthermore, the clearance of $\mathrm{CD}^{+} \mathrm{H} 2-\mathrm{Kb}$ SIINFEKL ${ }^{+}$ $\mathrm{T}$ cells from the lungs through draining lymphatics could lead to the recruitment of allergen-specific $\mathrm{CD} 8^{+} \mathrm{T}$ cells into the liver, as has been described in other models of infection or inflammation (41-43).

Why are these allergen-specific CD8 ${ }^{+} \mathrm{T}$ cells induced in such significant numbers by an extracellular antigen in the memory phase after OVA-aerosol challenge? Various recent publications have defined the phenomenon of cross-presentation. This type of antigen processing describes the association of soluble, extracellular antigens and their respective immunogenic peptides to MHC-I molecules, and it is dependent on intracellular membrane fusion processes, which allows the passage of soluble antigen peptides into the endoplasmic reticulum where adequate peptides can be loaded onto MHC-I molecules (44). In contrast to these recent data, not all groups working in the field have agreed to the phenomenon of cross-presentation as a physiological pathway (45). We tried to address this question in our murine model of allergic inflammation by using adoptive transfer of OT-I cells with TAP1 $1^{-1-}$ mice in the memory response to soluble OVA-aerosol challenge. Although strong activation of adoptively transferred $\mathrm{CD} 8^{+} \mathrm{H} 2-\mathrm{Kb}$ SIINFEKL ${ }^{+} \mathrm{T}$ cells (OT-I cells) occurred in the lungs of control wild-type C57BL/6 mice after OVA-aerosol challenge in lung tissue and in BAL fluid, no activation of OT-I cells was seen in TAP1 $1^{-1-}$ mice after allergen exposure. This demonstrates the existence of a cross-priming pathway in the OVA allergy model that is operative in vivo and is TAP dependent.

Because OVA preparations are commonly contaminated with LPS and because LPS and its compounds are known to influence allergic reactions $(46,47)$ we included spiking experiments in our study to rule out the possibility that the amount of LPS in the OVA preparation and not the amount of OVA itself was responsible for CD8 induction. This experiment revealed that LPS itself had only a minor effect on the induction of SIINFEKL-specific CD8-T cells. Thus, LPS seems not to be responsible for the observed cross-presentation.

The role of $\mathrm{CD}^{+} \mathrm{T}$ cells in rodent models of IgE-mediated allergy has been discussed in previous publications. Although some reports suggested a beneficial role of allergen-specific $\mathrm{CD}^{+} \mathrm{T}$ cells by increasing IL-12 production in respiratory dendritic cells through direct interaction $(6,12)$ or by IFN- $\gamma$ (48), others identified a detrimental role of allergen-specific $\mathrm{CD}^{+} \mathrm{T}$ cells for the severity of IgE-mediated allergy and airway inflammation by virtue of their ability to produce IL-13 and thereby aggravate allergic symptoms $(4,17,49)$. Our results argue in favor of a protective role of allergen-specific $\mathrm{CD} 8^{+} \mathrm{T}$ cells because their numbers inversely correlated to phenotype markers of IgE-mediated allergy and airway inflammation, such as plasma IgE, airway eosinophilia, and IL-4 levels in BAL fluid. Moreover, using TAP1 ${ }^{-1-}$ mice in the low-dose model, we found higher degrees of cell infiltration and increased production of $\operatorname{IgE}$ as compared with wild-type mice undergoing the same protocol. Furthermore, in lung function tests, $10 \mu \mathrm{g}$ OVA $\mathrm{TAP}^{-1-}$ mice showed similar but lower values of $\mathrm{R}$ and specific resistance compared with $10 \mu \mathrm{g}$ OVA wild-type mice, which did not reach statistical significance when compared with control mice; on the other hand, they showed a notable reduction in $\mathrm{DL}_{\mathrm{CO}}$ compared with control mice, most likely due to peripheral pulmonary inflammation. The $\mathrm{TAP} 1^{-/-}$mouse is thereby probably better suited than $\mathrm{CD} 8 \alpha^{-/-}$or anti-CD8 antibody-treated mice because the repertoire of dendritic cells expressing $\mathrm{CD} 8 \alpha$ is intact in this model. Furthermore, the $\mathrm{TAP}^{-1-}$ model targets the induction of OVA-specific $\mathrm{CD} 8^{+}$ $\mathrm{T}$ cells by way of defective cross presentation of exogenous antigen (50). Our results are in agreement with previous findings using the depletion of $\mathrm{CD} 8^{+} \mathrm{T}$ cells in models of allergic airway inflammation $(7,51)$.

In summary, our study shows the antigen dose-dependent induction of effector $\mathrm{CD} 8^{+} \mathrm{T}$ cells with specificity for the soluble antigen OVA in different sensitization protocols using high- or low-dose OVA concentrations. These cells follow a natural course of kinetics similar to intracellular infections with the characteristics of $\mathrm{CD} 8^{+} \mathrm{T}$-cell reduction after primary allergic sensitization and strong expansion after encountering allergen on rechallenge. These allergen-specific $\mathrm{CD}^{+} \mathrm{T}$ cells are induced in a dose-dependent manner by cross-priming, and their further expansion on allergen encounter depends on a functional TAP-1 complex. In line, in TAP1 ${ }^{-/-}$mice, IgE responses and symptoms of allergic inflammatory airway reactions are enhanced. The number of allergen specific $\mathrm{CD} 8^{+} \mathrm{T}$ cells appears to be a critical predictor for the severity of the allergic phenotype in this murine model. Allergen-specific $\mathrm{CD}^{+} \mathrm{T}$ cells showing a similar phenotype with high production of IFN- $\gamma$ have also been found in humans. Similar to our murine allergy model, the presence of allergen-specific $\mathrm{CD} 8^{+} \mathrm{T}$ cells in patients was correlated to a less severe expression of allergic disease (52). Thus, it is reasonable to speculate that $\mathrm{CD} 8^{+} \mathrm{T}$ cells could play a role in acquiring and/or maintaining a state of clinical tolerance toward an allergenic stimulus in IgE-mediated allergic diseases. 
Conflict of Interest Statement: J.A.A-P. does not have a financial relationship with a commercial entity that has an interest in the subject of this manuscript. F.A. does not have a financial relationship with a commercial entity that has an interest in the subject of this manuscript. K.M.H. does not have a financial relationship with a commercial entity that has an interest in the subject of this manuscript. T.J. has been on the Executive Committee of the European Academy of Allergy and Clinical Immunology (2005-2009), some of whose activities have been financed by unrestricted grants from industry. For details visit www.eaaci. net. T.J. is a board member of the European Immunodermatology Society and the German Society of Allergy and Clinical Immunology, some of whose activities have been financed by unrestricted grants from industry. T.J. received research grants from Phadia (2007-2009) and the European Cosmetics Association COLIPA A.I.S.B.L. (2009-2012). T.J. has participated in multicenter clinical trials by Schering Plough, Novartis, and Genentech. T.J. has participated in scientific meetings and courses organized and financed by various companies (ALK Abello, Astellas, Allergopharm, Beckmann, Schering Plough, Novartis). H.S. does not have a financial relationship with a commercial entity that has an interest in the subject of this manuscript. H.B. does not have a financial relationship with a commercial entity that has an interest in the subject of this manuscript. J.R. or a member of J.R.'s immediate family or household served as an investigator for Novartis, Fujisawa, GlaxoSmithKline, Bencard, Stallergenes, Abella/ALK, Allergopharma, Pharmacia, CPC Biermann, Avenntis Almirall, Leo, Galderma, and Switch Biotech for clinical trials, and Schering-Plough for basic research. M.H.d.A. does not have a financial relationship with a commercial entity that has an interest in the subject of this manuscript. D.H.B. does not have a financial relationship with a commercial entity that has an interest in the subject of this manuscript. M.M. received $\$ 1,001-\$ 5,000$ from Novartis for serving on an advisory board, $\$ 10,001-\$ 50,000$ for Wyeth in industry-sponsored grants for TNF in skin disease, and $\$ 10,001-\$ 50,000$ as an employee of DFG. M.O. does not have a financial relationship with a commercial entity that has an interest in the subject of this manuscript.

Acknowledgment: The authors thank B. Heuser, B. Maar, M. Skerhut, C. Zeller, and G. Eder for technical assistance.

\section{References}

1. Kay AB. Allergy and allergic diseases: first of two parts. $N$ Engl J Med 2001;344:30-37.

2. Nakajima H, Iwamoto I, Tomoe S, Matsumura R, Tomioka H, Takatsu $\mathrm{K}$, Yoshida S. CD4+ T-lymphocytes and interleukin-5 mediate antigen-induced eosinophil infiltration into the mouse trachea. Am Rev Respir Dis 1992;146:374-377.

3. Gavett SH, Chen X, Finkelman F, Wills-Karp M. Depletion of murine $\mathrm{CD} 4+\mathrm{T}$ lymphocytes prevents antigen-induced airway hyperreactivity and pulmonary eosinophilia. Am J Respir Cell Mol Biol 1994;10:587-593.

4. Miyahara N, Swanson BJ, Takeda K, Taube C, Miyahara S, Kodama T, Dakhama A, Ott VL, Gelfand EW. Effector CD8+ T cells mediate inflammation and airway hyper-responsiveness. Nat Med 2004;10:865-869.

5. Stock P, Kallinich T, Akbari O, Quarcoo D, Gerhold K, Wahn U, Umetsu DT, Hamelmann E. CD8 $(+)$ T cells regulate immune responses in a murine model of allergen-induced sensitization and airway inflammation. Eur J Immunol 2004;34:1817-1827.

6. Wells JW, Cowled CJ, Giorgini A, Kemeny DM, Noble A. Regulation of allergic airway inflammation by class I-restricted allergen presentation and CD8 T-cell infiltration. J Allergy Clin Immunol 2007;119:226-234.

7. Tsuchiya $\mathrm{K}$, Isogai $\mathrm{S}$, Tamaoka $\mathrm{M}$, Inase $\mathrm{N}$, Akashi $\mathrm{T}$, Martin JG, Yoshizawa Y. Depletion of CD8 + T cells enhances airway remodelling in a rodent model of asthma. Immunology 2009;126:45-54.

8. Gardner LM, Spyroglou L, O'Hehir RE, Rolland JM. Increased allergen concentration enhances IFN-gamma production by allergic donor $\mathrm{T}$ cells expressing a peripheral tissue trafficking phenotype. Allergy 2004;59:1308-1317.

9. Pooley JL, Heath WR, Shortman K. Cutting edge: intravenous soluble antigen is presented to CD4 T cells by CD8- dendritic cells, but cross-presented to CD8 T cells by CD8+ dendritic cells. J Immunol 2001;166:5327-5330.

10. Pozzi LA, Maciaszek JW, Rock KL. Both dendritic cells and macrophages can stimulate naive CD8 T cells in vivo to proliferate, develop effector function, and differentiate into memory cells. J Immunol 2005;175:2071-2081.

11. Staerz UD, Karasuyama H, Garner AM. Cytotoxic T lymphocytes against a soluble protein. Nature 1987;329:449-451.

12. Thomas MJ, Noble A, Sawicka E, Askenase PW, Kemeny DM. CD8 T cells inhibit IgE via dendritic cell IL-12 induction that promotes Th1 T cell counter-regulation. J Immunol 2002;168:216-223.

13. Kemeny DM. CD8+ T cells in atopic disease. Curr Opin Immunol 1998; 10:628-633.

14. Holmes BJ, MacAry PA, Kemeny DM. Depletion of CD8+ T cells following primary immunization with ovalbumin results in a high and persistent IgE response. Int Arch Allergy Immunol 1997;113:160-162.
15. Allakhverdi Z, Lamkhioued B, Olivenstein R, Hamid Q, Renzi PM. CD8 depletion-induced late airway response is characterized by eosinophilia, increased eotaxin, and decreased IFN-gamma expression in rats. Am J Respir Crit Care Med 2000;162:1123-1131.

16. Seymour BW, Gershwin LJ, Coffman RL. Aerosol-induced immunoglobulin (Ig)-E unresponsiveness to ovalbumin does not require $\mathrm{CD} 8+$ or $\mathrm{T}$ cell receptor (TCR)-gamma/delta $+\mathrm{T}$ cells or interferon (IFN)-gamma in a murine model of allergen sensitization. $J$ Exp Med 1998;187:721-731.

17. Miyahara N, Takeda K, Kodama T, Joetham A, Taube C, Park JW, Miyahara S, Balhorn A, Dakhama A, Gelfand EW. Contribution of antigen-primed CD8 $+\mathrm{T}$ cells to the development of airway hyperresponsiveness and inflammation is associated with IL-13. J Immunol 2004;172:2549-2558.

18. O'Sullivan S, Cormican L, Faul JL, Ichinohe S, Johnston SL, Burke CM, Poulter LW. Activated, cytotoxic CD8(+) Tlymphocytes contribute to the pathology of asthma death. Am J Respir Crit Care Med 2001;164:560-564.

19. Akdis CA, Blaser K, Akdis M. Mechanisms of allergen-specific immunotherapy. Chem Immunol Allergy 2006;91:195-203.

20. Gabrielsson S, Soderlund A, Paulie S, van der Pouw Kraan TC, TroyeBlomberg M, Rak S. Specific immunotherapy prevents increased levels of allergen-specific IL-4- and IL-13-producing cells during pollen season. Allergy 2001;56:293-300.

21. Blaser K, Carballido J, Faith A, Crameri R, Akdis C. Determinants and mechanisms of human immune responses to bee venom phospholipase A2. Int Arch Allergy Immunol 1998;117:1-10.

22. Platts-Mills TA, Vaughan JW, Blumenthal K, Pollart Squillace S, Sporik RB. Serum IgG and IgG4 antibodies to Fel d 1 among children exposed to 20 microg Fel d 1 at home: relevance of a nonallergic modified Th2 response. Int Arch Allergy Immunol 2001;124:126-129.

23. Bousquet J, Lockey R, Malling HJ. Allergen immunotherapy: therapeutic vaccines for allergic diseases. A WHO position paper. J Allergy Clin Immunol 1998;102:558-562.

24. Moffitt JE, Golden DB, Reisman RE, Lee R, Nicklas R, Freeman T, deshazo R, Tracy J, Bernstein IL, Blessing-Moore J, et al. Stinging insect hypersensitivity: a practice parameter update. J Allergy Clin Immunol 2004;114:869-886.

25. Secrist $\mathrm{H}$, DeKruyff $\mathrm{RH}$, Umetsu DT. Interleukin 4 production by $\mathrm{CD} 4+\mathrm{T}$ cells from allergic individuals is modulated by antigen concentration and antigen-presenting cell type. J Exp Med 1995;181: 1081-1089.

26. Sakai K, Yokoyama A, Kohno N, Hiwada K. Effect of different sensitizing doses of antigen in a murine model of atopic asthma. Clin Exp Immunol 1999;118:9-15.

27. Morokata T, Ishikawa J, Yamada T. Antigen dose defines T helper 1 and $\mathrm{T}$ helper 2 responses in the lungs of $\mathrm{C} 57 \mathrm{BL} / 6$ and $\mathrm{BALB} / \mathrm{c}$ mice independently of splenic responses. Immunol Lett 2000;72:119-126.

28. Klenerman P, Cerundolo V, Dunbar PR. Tracking T cells with tetramers: new tales from new tools. Nat Rev Immunol 2002;2:263-272.

29. Aguilar-Pimentel A, Huster K, Alessandrini F, Jakob T, Behrendt H, Ring J, Busch DH, Mempel M, Ollert M. Modulation of the antigen dose during allergic sensitization reveals a key role for CD8+ T cells in reducing allergic airway inflammation. Allergy 2008;63:s88.

30. Aguilar-Pimentel JA, Huster K, Alessandrini F, Gutermuth J, Jakob T, Behrendt H, Ring J, Busch D, Mempel M, Ollert M. De novo induction and recruitment of allergen-specific effector CD8+ T cells in a mouse model of IgE-mediated allergy and airway inflammation. J Allergy Clin Immunol 2005;115:S274.

31. Alessandrini F, Schulz H, Takenaka S, Lentner B, Karg E, Behrendt H, Jakob T. Effects of ultrafine carbon particle inhalation on allergic inflammation of the lung. J Allergy Clin Immunol 2006;117:824-830.

32. Frentsch M, Arbach O, Kirchhoff D, Moewes B, Worm M, Rothe M, Scheffold A, Thiel A. Direct access to CD4+ T cells specific for defined antigens according to CD154 expression. Nat Med 2005;11: 1118-1124.

33. Wherry EJ, Teichgraber V, Becker TC, Masopust D, Kaech SM, Antia R, von Andrian UH, Ahmed R. Lineage relationship and protective immunity of memory CD8 T cell subsets. Nat Immunol 2003;4:225-234.

34. Huster KM, Busch V, Schiemann M, Linkemann K, Kerksiek KM, Wagner H, Busch DH. Selective expression of IL-7 receptor on memory $\mathrm{T}$ cells identifies early CD40l-dependent generation of distinct CD8+ memory $\mathrm{T}$ cell subsets. Proc Natl Acad Sci USA 2004;101:5610-5615.

35. Jaakkola I, Merinen M, Jalkanen S, Hanninen A. Ly6C induces clustering of LFA-1 (CD11a/CD18) and is involved in subtypespecific adhesion of CD8 T cells. J Immunol 2003;170:1283-1290. 
36. Curtsinger JM, Lins DC, Mescher MF. CD8+ memory $\mathrm{T}$ cells (CD44high, Ly-6C+) are more sensitive than naive cells to (CD44low, Ly-6C-) to TCR/CD8 signaling in response to antigen. J Immunol 1998;160:3236-3243.

37. Ashton-Rickardta PG, Opferman JT. Memory T lymphocytes. Cell Mol Life Sci 1999;56:69-77.

38. Schaller MA, Lundy SK, Huffnagle GB, Lukacs NW. CD8+ T cell contributions to allergen induced pulmonary inflammation and airway hyperreactivity. Eur J Immunol 2005;35:2061-2070.

39. Knabel M, Franz TJ, Schiemann M, Wulf A, Villmow B, Schmidt B, Bernhard H, Wagner H, Busch DH. Reversible MHC multimer staining for functional isolation of $\mathrm{T}$-cell populations and effective adoptive transfer. Nat Med 2002;8:631-637.

40. Koelle DM, Liu Z, McClurkan CM, Topp MS, Riddell SR, Pamer EG, Johnson AS, Wald A, Corey L. Expression of cutaneous lymphocyteassociated antigen by CD8(+) T cells specific for a skin-tropic virus. J Clin Invest 2002;110:537-548.

41. Masopust D, Vezys V, Usherwood EJ, Cauley LS, Olson S, Marzo AL, Ward RL, Woodland DL, Lefrancois L. Activated primary and memory CD8 $\mathrm{T}$ cells migrate to nonlymphoid tissues regardless of site of activation or tissue of origin. J Immunol 2004;172:4875-4882.

42. Dikopoulos N, Jomantaite I, Schirmbeck R, Reimann J. Specific, functional effector/memory CD8 $+\mathrm{T}$ cells are found in the liver post-vaccination. J Hepatol 2003;39:910-917.

43. Yoshida A, Ohba M, Wu X, Sasano T, Nakamura M, Endo Y. Accumulation of platelets in the lung and liver and their degranulation following antigen-challenge in sensitized mice. Br J Pharmacol 2002; $137: 146-152$

44. Ackerman AL, Kyritsis C, Tampe R, Cresswell P. Early phagosomes in dendritic cells form a cellular compartment sufficient for cross pre- sentation of exogenous antigens. Proc Natl Acad Sci USA 2003;100: 12889-12894.

45. Zinkernagel RM. On cross-priming of MHC class I-specific CTL: rule or exception? Eur J Immunol 2002;32:2385-2392.

46. Drachenberg KJ, Wheeler AW, Stuebner P, Horak F. A well-tolerated grass pollen-specific allergy vaccine containing a novel adjuvant, monophosphoryl lipid a, reduces allergic symptoms after only four preseasonal injections. Allergy 2001;56:498-505.

47. Delayre-Orthez C, de Blay F, Frossard N, Pons F. Dose-dependent effects of endotoxins on allergen sensitization and challenge in the mouse. Clin Exp Allergy 2004;34:1789-1795.

48. Yoshida M, Leigh R, Matsumoto K, Wattie J, Ellis R, O'Byrne PM, Inman MD. Effect of interferon-gamma on allergic airway responses in interferon-gamma-deficient mice. Am J Respir Crit Care Med 2002; 166:451-456.

49. Dakhama A, Park JW, Taube C, Joetham A, Balhorn A, Miyahara N, Takeda K, Gelfand EW. The enhancement or prevention of airway hyperresponsiveness during reinfection with respiratory syncytial virus is critically dependent on the age at first infection and IL-13 production. J Immunol 2005;175:1876-1883.

50. Van Kaer L, Ashton-Rickardt PG, Ploegh HL, Tonegawa S. TAP1 mutant mice are deficient in antigen presentation, surface class I molecules, and CD4-8+ T cells. Cell 1992;71:1205-1214.

51. Huang TJ, MacAry PA, Kemeny DM, Chung KF. Effect of CD8+ T-cell depletion on bronchial hyper-responsiveness and inflammation in sensitized and allergen-exposed Brown-Norway rats. Immunology 1999;96:416-423.

52. Seneviratne SL, Jones L, King AS, Black A, Powell S, McMichael AJ, Ogg GS. Allergen-specific CD8(+) T cells and atopic disease. J Clin Invest 2002;110:1283-1291. 